\title{
Identification of Fish Prey of an Irrawaddy Dolphin (Orcaella brevirostris) using Mitochondrial Cytochrome c Oxidase 1 Sequence Analysis
}

\author{
John François L. Postrado ${ }^{1 \star}$, Katrina Ma. Antonia J. Jover ${ }^{1}$, Hannah Jezreel D. Mabulac ${ }^{1}$, John Simon B. Velasco ${ }^{1}$, \\ Manuel Eduardo L. de la Paz ${ }^{1}$, Jacqueline Marjorie R. Pereda ${ }^{2}$, Minerva Fatimae H. Ventolero ${ }^{2}$, \\ Mudjekeewis D. Santos ${ }^{2}$ \\ ${ }^{1}$ University of St. La Salle, La Salle Avenue, Bacolod City 6100, Negros Occidental, Philippines \\ ${ }^{2}$ Genetic Fingerprinting Laboratory, National Fisheries Research and Development Institute Corporate 101 Building, \\ Mother Ignacia Ave., South Triangle, Quezon City 1103 Philippines
}

\begin{abstract}
A B S T R A C T
This study used mitochondrial cytochrome c oxidase 1 in the identification of the fish prey from the gut samples collected from a stranding of a dead Irrawaddy dolphin in Pulupandan, Negros Occidental. Obtained consensus sequences were searched against the nucleotide database of NCBI and reference sequences, and sample sequences were used for generating the dendrogram and the pairwise genetic distances between species. Results showed that most of the sample sequences were $99 \%$ identical to the reference sequences. Eubleekeria splendens and Conger japonicus were the identified species in the stomach contents. E. splendens is a demersal and coastal species while $C$. japonicus is a demersal species and has not been previously recorded in the Philippines. Conflict in the taxonomy of the Conger genus may suggest that this may be identified as $C$. jordani. This study reports the first record of fish prey identification of the Irrawaddy dolphin in the country. Continuous monitoring of the Irrawaddy dolphin in the Guimaras Strait, including their feeding ecology, is needed to understand the population further and to improve their conservation.
\end{abstract}

E-mail address: johnfrancoispostrado@gmail.com*

Received: November 7, 2018

Accepted: January 29, 2019
Keywords: Irrawaddy dolphins, DNA barcoding, mitochondrial cytochrome c oxidase 1 , gut contents

\section{I N T R O D UCT I O N}

1 he Irrawaddy dolphin, Orcaella brevirostris, is a marine mammal thriving in river systems, estuaries, and in coastal environments in the Indo-west Pacific. It is classified globally by the IUCN Red List as endangered (Minton et al. 2017) and faces threats including gillnet entanglement, habitat degradation, increased industrial activities, pollution, overfishing of prey species, and capture for trading (Minton et al. 2017; Reeves et al. 2008; Smith and Jefferson 2002; Tun 2014). In the Philippines, it was first recorded in Malampaya Sound, Palawan (Dolar et al. 2002; Smith et al. 2004) and more recently in 2010, in the coastal waters of Bago and Pulupandan, Negros Occidental (Alava et al. 2012; de la Paz 2012; Dolar et al. 2002).

Proper management of this species is dependent on sound scientific data. While studies on their population and habitat use (Casipe et al. 2015; de la Paz 2012) have contributed to identifying priority areas for management, a better understanding of their feeding ecology helps managers ensure the sustainability of their food resources. Prerequisite to this is the identification of their prey preferences. Prey species preference differs among various subpopulations. A stomach contents analysis conducted on two Irrawaddy dolphins from Mekong River, Cambodia resulted in unidentified species of shrimp and several species of cyprinid fish (Lloze 1973). Another stomach contents analysis of stranded dolphins in Trat Bay, Thailand also found prey species consisting of shrimp, tiger prawn, cuttlefish, octopus, soft cuttlefish, croaker, yellow-stripe scad, anchovy, and mackerel (Junchompoo et al. 2014). In Queensland, Australia, Parra and Jedensō (2009) examined the stomachs of 14 stranded and bycaught snubfin dolphins (O. heinsohni) and found a variety of bottom-dwelling pelagic fishes such as cardinalfish and ponyfish, as well as cephalopods like cuttlefish and squid. 
A stranding of an Irrawaddy dolphin in the Philippines paved a way to study this species' diet composition. Divinagracia et al. (2015) assessed the stomach contents of the stranded dolphin using sagittal otoliths and semi-digested skeletal remains of the fishes and subsequently identified them to the family level. Although the use of otoliths for species and fish stock identification is well established and has been extensively used in the identification of fish prey of many cetacean

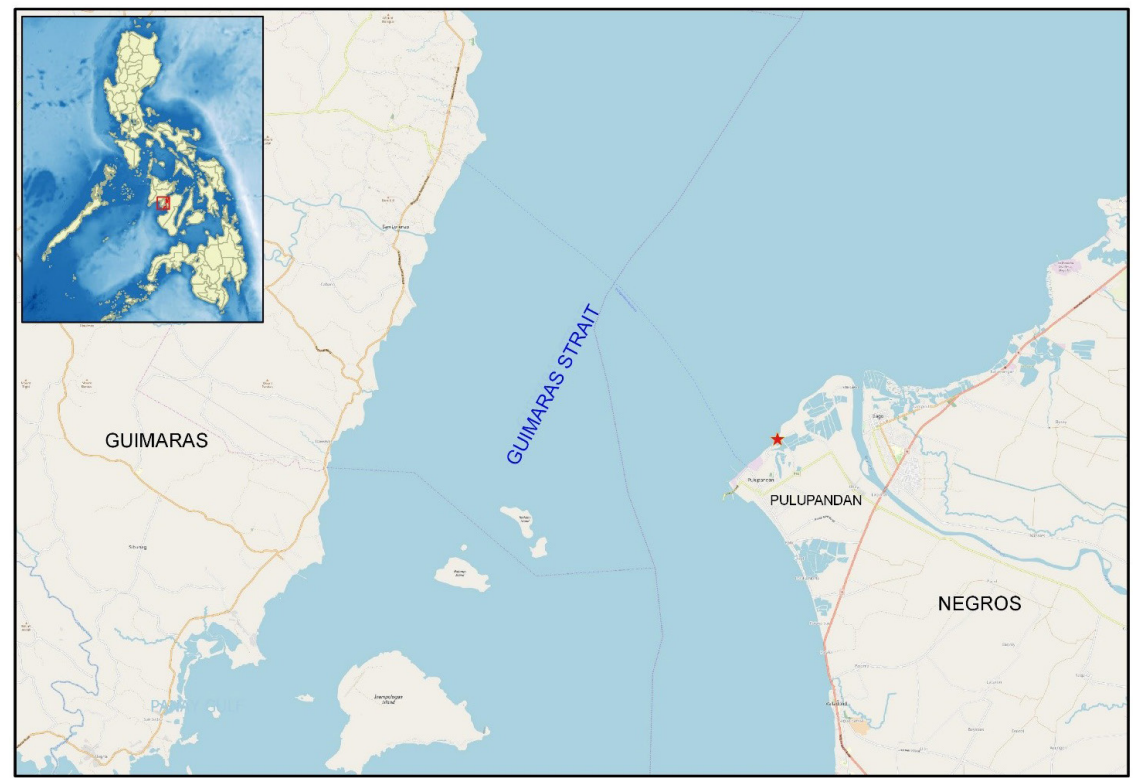

Figure 1. Stranding location of an Irrawaddy dolphin in Pulupandan, Negros Occidental (marked by a star), whose stomach contents were used for the analysis. species, misidentification is still possible. This is due to the morphological similarities of the otoliths of closely related species, which may cause subjectivity in the assignment of species (Alonso et al. 2013; Bowen and Iverson 2013).

DNA barcoding offers a more accurate way to identify these species. This molecular method utilizes one or a few relatively short gene sequences taken from a standardized portion of the genome (Kress et al. 2014). One of the sequences extensively utilized for DNA barcoding is the mitochondrial cytochrome $c$ oxidase subunit 1 gene (CO1) (Hebert et al. 2003). Its efficacy in fish species identification has been exhibited in several studies (Agmata et al. 2013; Hubert et al. 2008; Sarmiento et al. 2018; Ward et al. 2005; Zhang and Hanner 2011). Thus this study utilized the CO1 gene to identify the fish prey of the stranded Irrawaddy dolphin and to subsequently link the ecology of these fish preys to the feeding habits of the dolphins.

\section{MATERIALS AND METHODS}

Nineteen fish samples were obtained from the stomach of a Code 2 (freshly dead) stranded Irrawaddy dolphin on July 1,2013 , in the coast of Pulupandan, Negros Occidental (Guimaras Strait) (Fig. 1). Samples collected were described as semi-digested and were mostly composed of bone and muscle. The samples were preserved in $70 \%$ ethanol, and about 150 mg of muscle tissue was obtained from every sample (Fig. 2). DNA extraction was based on the method of Grewe et al. (1993).
An approximately 650 base pair fragment of the mitochondrial cytochrome $c$ oxidase subunit 1 gene was amplified using primers F2 and R1 from Ward et al. (2005). The PCR mix included distilled water $(12.3 \mu \mathrm{L}), 10 \mathrm{X}$ PCR buffer with $\mathrm{MgCl}_{2}(2.5 \mu \mathrm{L}), 2$ mM dNTPs $(2.5 \mu \mathrm{L}), 25 \mathrm{mM} \mathrm{MgCl}_{2}(2.5 \mu \mathrm{L})$, Taq polymerase $(0.2 \mu \mathrm{L}), \mathrm{F} 2$ Primer $(2 \mu \mathrm{L}), \mathrm{R} 1$ Primer $(2 \mu \mathrm{L})$, and DNA template $(2 \mu \mathrm{L})$ were mixed in a PCR tube to make a $24 \mu \mathrm{L}$ reaction per sample. The PCR conditions were as follows: initial denaturation at $95^{\circ} \mathrm{C}$ for $5 \mathrm{~min}$; 35 cycles of denaturation at $95^{\circ} \mathrm{C}$ for $30 \mathrm{~s}$, annealing at $50^{\circ} \mathrm{C}$ for $1 \mathrm{~min}$, extension at $72^{\circ} \mathrm{C}$ for $1 \mathrm{~min}$ and $30 \mathrm{~s}$; and a final extension at $72^{\circ} \mathrm{C}$ for $5 \mathrm{~min}$. The PCR amplicons were sent to AITbiotech, Singapore for bidirectional sequencing. Sequence analysis was done by the construction of a dendrogram via MEGA 6 (Tamura et al. 2013) using the Neighbor-Joining method and also computing pairwise genetic distances using Kimura 2-parameter model (Kimura 1980) from the sample and reference sequences from GenBank. Siganus guttatus was used as an outgroup. This study focused only on the fish prey obtained from the gut of a male Irrawaddy dolphin which stranded on the coastal waters of Bago-Pulupandan on July 2013 and is limited by the gut content with viable muscle tissue for analysis. The CO1 gene is the sole basis for species identification.

\section{RESULTSAND D ISCUSSION}

Sixteen out of 19 samples yielded bands following gel electrophoresis which were viewed under 


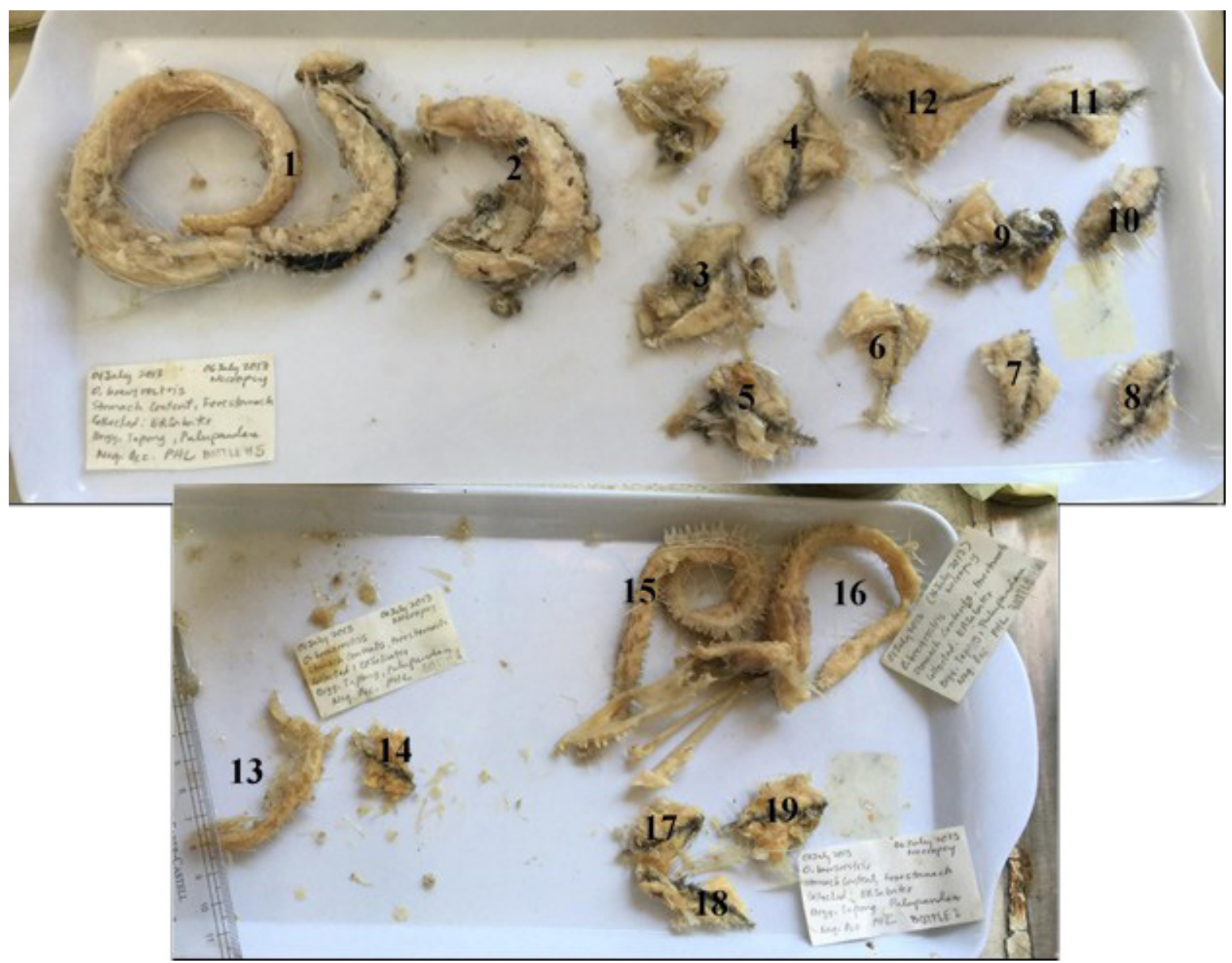

Figure 2. Fish samples from gut content.

UV light (Fig. 3). The samples that did not yield bands indicate failure of the $\mathrm{CO} 1$ gene amplification.

Fifteen samples were successfully sequenced; however, three samples did not match with any of the nucleotide sequences when these were subjected to the BLAST search, leaving 12 samples for identification. Figure 4 shows the neighbor-joining tree generated using the sample sequences and the reference sequences from the nucleotide database.

Ten of the fish samples clustered with $\mathbf{E u}$ bleekeria splendens/splendid ponyfish (synonymous to Leiognathus philippinus) sequence obtained from the GenBank database. The CO1 sequences of samples $4,6,7,8,9,11$, $12,14,18$, and 19 were $99 \%$ identical to the E. splendens reference sequence $(\mathrm{E}$ value $=$ 0.0 ). The other two fish samples clustered with the Conger japonicus/beach conger reference sequence. The $\mathrm{CO} 1$ sequences of samples 1 and 2 had $92 \%$ and $99 \%$ sequence similarity with the $C$. japonicus ref- erence sequence, respectively $(\mathrm{E}$ value $=0.0)$.

The results indicate that the stranded Irrawaddy dolphin fed on E. splendens and C. japonicus. The identification is in corroboration with the identification of Divinagracia et al. (2015), who identified the Leiognathidae and Anguilliformes groups using otolith samples.

The identities of the fishes were further confirmed using their pairwise distances; the closer the value to 0 , the more genetically identical the sample sequence is to the reference sequence. Samples 4, 6,

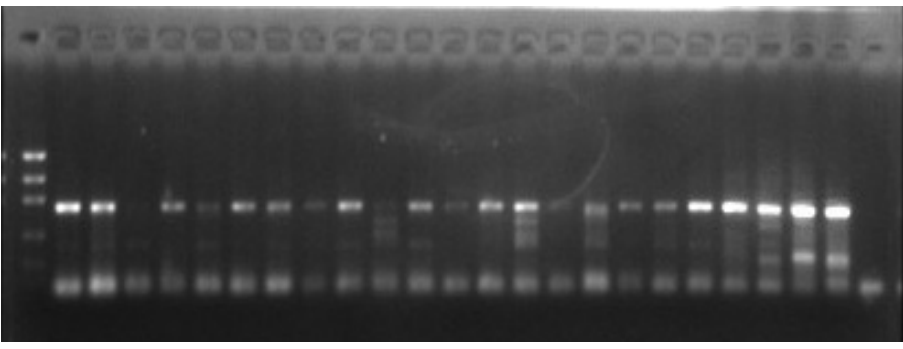

Figure 3. UV visualization of bands after gel electrophoresis. 


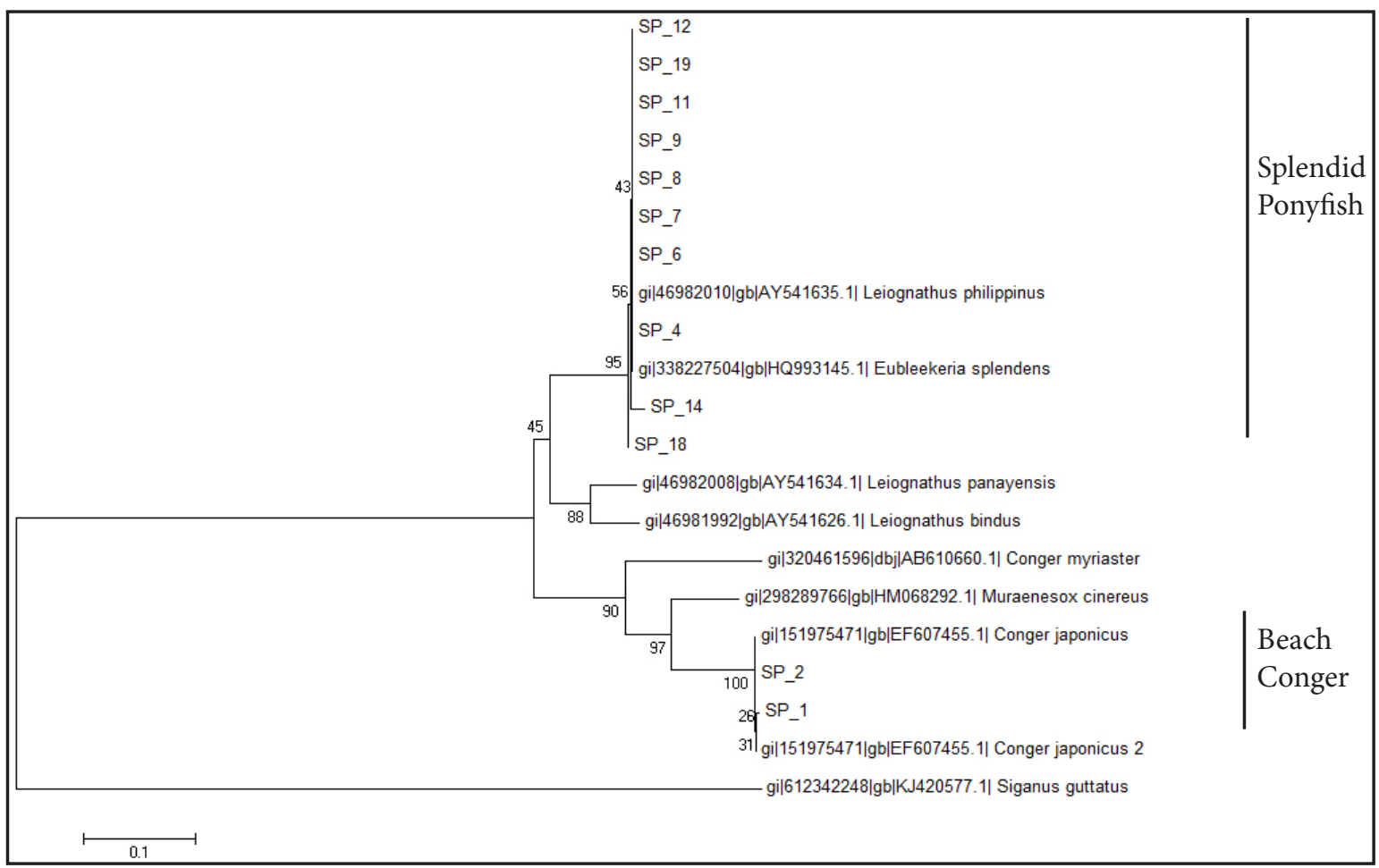

Figure 4. Neighbor-joining tree of dolphin fish prey and GenBank reference sequences using the Kimura 2-parameter model.

$7,8,9,11,12$, and 19 are in the same branch with $E$. splendens (or L. philippinus) and is supported by their mean pairwise distance to E. splendens sequences of 0.000. Samples 14 and 18, are also clustered with $E$. splendens with small mean genetic distances to the E. splendens sequences, 0.013 and 0.002 , respectively. The K2P distances among the samples which clustered with the E. splendens sequences range from 0.000 to 0.013 with a mean distance of 0.006 . Samples 1 and 2 were also very similar to the $C$. japonicus sequences with mean distances of 0.002 and 0.000 , respectively; the K2P distance between samples is 0.002 .

While the genetic analysis points to the identity of the two specimens as C. japonicus, the species has been designated as synonymous to Conger myriaster, or the whitespotted conger (Smith et al. 2016). Whitespotted congers are distributed in the northwest Pacific, encompassing Japan, the Korean peninsula, and Taiwan (Masuda et al. 1984). However, further conflict in the taxonomy of the Conger genus suggests that specimens reported in the Philippines are likely to be C. jordani, as these are widely distributed in Taiwan, and most probably the Philippines (D. Smith pers. comm.). The genus is composed of marine and demersal bony, ray-finned fishes that live in rock bottoms ranging from 1 to 276 meters in depth. It belongs to the family Congridae, a group of economically valuable fish species.
Studies conducted on other cetaceans such as the pantropical spotted dolphin (Stenella attenuata) off the eastern coast of Taiwan (Wang et al. 2003) and the Fraser's dolphins (Lagenodelphis hosei) in the eastern Sulu Sea, Philippines (Dolar et al. 2003) found fishes from the Congridae family in the stomach contents of these dolphins. Thus, it is not unlikely for dolphins to feed on congers, and the most probable means in order to acquire this demersal fish is to dive near the seafloor where beach congers can be found.

Splendid ponyfish is distributed throughout eastern Indian and western Pacific waters the whole year-round (Hajisamae et al. 2006). This fish is common among coastal waters and estuaries, but are also present in brackish and marine areas (Kimura et al. 2005). In the South China Sea, they account for one of the most dominant species in the coastal areas (Hajisamae and Yeesin 2010). Their high preference for shallow coastal areas is primarily due to their diet of shallow-dwelling shrimps, squid, and cuttlefish (Kimura et al. 2005). Their habitat distribution coincides with that of the Irrawaddy dolphin, as this is the most common species found in the stomach analysis. In Queensland, Australia, ponyfishes were among the species identified by Parra and Jendensō (2009) in the guts of stranded and bycaught snubfin dolphins.

Splendid ponyfish is among the most-caught species in the western-central Pacific fisheries region, 
along with scads, Indian mackerel, skipjack tuna, and milkfish. Moreover, the Philippines is one of four countries making top fishery contributions within this region (Hart and Pitcher 1982).

In the Philippines, studies of Irrawaddy dolphin populations in Guimaras Strait (de la Paz 2012) and Malampaya Sound (Dolar et al. 2002) both state that more sightings occur within shallow areas near the shore, where the water is abundant in fish prey. Observations of the Guimaras Strait population show that when foraging, the dolphins prefer areas with high productivity where the food source is readily available (Casipe et al. 2015). There is no specific pattern of diving and surfacing observed within the population; asynchronous dives and fish herding techniques were observed and were categorized as foraging or feeding behavior. Moreover, the presence of sediment plumes was observed while the dolphins were foraging, which suggests that the dolphins engage in benthic and demersal feeding (de la Paz 2012) which can facilitate the vertical mixing and recycling of the limiting nutrients in the marine environment (Dewar et al. 2006).

\section{C O N C L U S I O N}

The genetic analysis of a stranded Irrawaddy dolphin's stomach contents through mitochondrial cytochrome c oxidase 1 was able to identify two species, namely, Eubleekeria splendens (synonymous to Leiognathus philippinus) or splendid ponyfish, and Conger japonicus or beach conger. E. splendens inhabits marine and coastal waters and estuaries while C. japonicus is purely marine. While there is still debate on the taxonomy of the Conger genus, both E. splendens and Conger spp. are demersal, although E. splendens may also be found in shallow waters. Species identification of prey of Irrawaddy dolphins is useful in allaying the fear or concern that the dolphins are a competition for the local fisheries especially if their prey is not the target species of the fisherfolk and, therefore, would encourage protection and conservation of the species.

The ecology of the identified species as well as supporting literature indicate that Irrawaddy dolphins dive to the seafloor regions for a moderate amount of time in order to forage. Although they spend the majority of their time inhabiting shallow and coastal waters, there are reported cases of Irrawaddy dolphins getting entangled in bottom-set nets and other seafloor-designed fishing. In a study of the Irrawaddy dolphin population in Malampaya Sound, Palawan, the use of these fishing gears were associated with deaths of Irrawaddy dolphins (Gonzales and Matillano 2008).
Hence, further studies of Irrawaddy dolphin feeding behavior and ecology will be of significant contribution to their conservation and management of fishing activities in their habitat.

\section{REFEREN C ES}

Agmata AB, Asis AMJM, Santos MD. 2013. Species identification of "padas" from fermented fish paste or "bagoong" using DNA barcodes. Philippines Science Letters 6(2): 220-224.

Alava MNR, Dolar MLL, Sabater ER, Aquino MTR, Santos MD. 2012. Red List Status of Marine Mammals in the Philippines. First edition. BFAR-NFRDI. $194 \mathrm{p}$.

Alonso H, Catry P, Granaidero P, Ramos J. 2013. Use the backbone of your samples: fish vertebrae reduce biases associated with otoliths in seabird diet studies. Journal of Ornithology, 154(3): 883-886.

Bowen WD, Iverson SJ. 2013. Methods of estimating marine mammal diets: a review of validation experiments and sources of bias and uncertainty. Mar Mamm Sci 29(4): 719-754. doi:10.1111/ j.1748-7692.2012.00604.x.

Casipe K, Espinosa KE, Jarabello CJ. 2015. Foraging Behavior Association Between Irrawaddy Dolphins and Tidal Net Fisheries [Thesis]. University of St. La Salle.

de la Paz, MEL. 2012. Behavior and Area Use of Irrawaddy Dolphins (Orcaella brevirostris, Gray 1886) in the Coastal Waters of Bago and Pulupandan, Negros Occidental, Philippines. [Thesis]. Silliman University.

Dewar WK, Bingham RJ, Iverson RL, Nowacek DP, St. Laurent LC, Wiebe PH. 2006. Does the marine biosphere mix the ocean? J Mar Res 64: 541561.

Divinagracia D, Sabater ER, Dolar, MLL. 2015. Identification of fish species using otoliths in Irrawaddy dolphin's stomach content. Poster presented at the 21st Biennial Conference on the Biology of Marine Mammals. San Francisco, California. 
Dolar MLL, Perrin WF, Gaudiano JP, Yaptinchay AASP, Tan JML. 2002. Preliminary Report on a Small Estuarine Population of Irrawaddy Dolphins Orcaella brevirostris in the Philippines. The Raffles Bulletin of Zoology Supplement 10: 155-160.

Dolar MLL, Walker WA, Kooyman GL, Perrin WF. 2003. Comparative feeding ecology of spinner dolphins (Stenella longirostris) and Fraser's dolphins (Lagenodelphis hosei) in the Sulu Sea. Mar Mamm Sci 19(1): 1-19.

Gonzales BJ, Matillano MV. 2008. Irrawaddy dolphin conservation in the fisheries of Malampaya Inner Sound, Palawan, Philippines. Mem Fac Fish. Kagoshima Univ. Special Issue: 16-25.

Grewe PM, Krueger C, Aquadro C, Bermingham E, Kincaid H, May B. 1993. Mitochondrial DNA variation among lake trout (Salvelinus namaycush) strains stocked into Lake Ontario. Canadian Journal of Fisheries and Aquatic Sciences 50(11): 2397-2403.

Hajisamae S, Yeesin P. 2010. Patterns in community structure of trawl catches along coastal area of the South China Sea. The Raffles Bulletin of Zoology 58(2): 357-368.

Hajisamae S, Yeesin P, Chaymongkol S. 2006. Habitat utilization by fishes in a shallow, semi-enclosed estuarine bay in southern Gulf of Thailand. Estuarine, Coastal and Shelf Science 68: 647-655.

Hart P, Pitcher TJ. 1982. Fisheries Ecology. 1st Ed., USA: Kluwer Academic Publishers. 414 p.

Hebert PDN, Cywinska A, Ball SL, deWaard JR. 2003. Biological identifications through DNA barcodes. Proceedings of the Royal Society B: Biological Sciences 270(1512): 313-321.

Hubert N, Hanner R, Holm E, Mandrak NE, Taylor E, Burridge M, Watkinson D, Dumont P, Curry A, Bentzen P, Zhang J, April J, Bernatchez L. 2008. Identifying Canadian Freshwater Fishes through DNA Barcodes. PLoS ONE 3(6): e2490.

Junchompoo C, Monanunsap S, Chatchai P. 2014. Population and Conservation Status of Irrawaddy
Dolphins (Orcaella brevirostris) in Trat Bay, Trat Province, Thailand. Proceedings of the Design Symposium on Conservation of Ecosystem (The 13th SEASTAR2000 Workshop) 2: 32-38. doi: http://dx.doi.org/10.14989/185132.

Kimura M. 1980. A simple method for estimating evolutionary rate of base substitutions through comparative studies of nucleotide sequences. J Mol Evol 16(2): 111-120.

Kimura S, Ito T, Peristiwady T. 2005. The Leiognathus splendens complex (Perciformes: Leiognathidae) with the description of a new species, Leiognathus kupanensis. Ichthyol Res 52(3): 275291.

Kress JW, Garcia-Robledo C, Uriarte M, Erickson DL. 2014. DNA Barcodes for Ecology, Evolution, and Conservation. Trends in Ecology and Conservation 30(1): 25-35.

Lloze R. 1973. Contributions a L'etude Anatomique, Histologique Et Biologique De L'Orcaella brevirostris (Gray, 1866) (Cetacea, Delphinidae) Du Mekong. [Dissertation]. L'Universite Paul Sabatier de Toulouse.

Masuda H, Amaoka K, Araga C, Uyeno T, Yoshino T. 1984. The fishes of the Japanese Archipelago. 1. Tokyo, Japan: Tokai University Press. 437 p.

Minton G, Smith BD, Braulik GT, Kreb D, Sutaria D, Reeves R. 2017. Orcaella brevirostris (errata version published in 2018). The IUCN Red List of Threatened Species 2017: e. T15419A123790805. Downloaded on $25 \mathrm{Au}-$ gust 2018.

Parra G, Jedensō M. 2009. Feeding habits of Australian Snubfin (Orcaella heinsohni) and Indo-Pacific humpback dolphins (Sousa chinensis). Project Report to the Great Barrier Reef Marine Park Authority, Townsville and Reef and Rainforest Research Centre Limited, Cairns. 22 p.

Reeves RR, Jefferson TA, Karczmarski L, Laidre K, O’Corry-Crowe G, Rojas-Bracho L, Secchi ER, Slooten E, Smith BD, Wang JY, Zhou K. 2008. Orcaella brevirostris. The IUCN Red List of Threatened Species 2008: e.T15419A4579987. 
Sarmiento KP, Pereda JMR, Ventolero MFH, Santos MD. 2018. Not fish in fish balls: fraud in some processed seafood products detected by using DNA barcoding. Philippine Science Letters 11(1): 30-36.

Smith BD, Beasley I, Buccat M, Calderon V, Evina R, De Valle JL, Visitacion Z. 2004. Status, ecology, and conservation of Irrawaddy dolphins (Orcaella brevirostris) in Malampaya Sound, Palawan, Philippines. Journal of Cetacean Research and Management 6(1): 41-52.

Smith BD, Jefferson TA. 2002. Status and conservation of facultative freshwater cetaceans in Asia. The Raffles Bulletin of Zoology Supplement 10: 173-187.

Smith DG, Schwarzhans WW, Pogonoski JJ. 2016. The Identity of Conger japonicus Bleeker, 1879 (Anguilliformes: Congridae). Copeia 104(3): 734737.

Tamura K, Stecher G, Peterson D, Filipski A, Kumar S. 2013. MEGA6: Molecular Evolutionary Genet- ics Analysis version 6.0. Mol Biol Evol 30(12): 2725-2729.

Tun T. 2014. Castnet Fishing with the Help of Irrawaddy Dolphin, Orcaella brevirostris, in Myanmar. Proceedings of the Design Symposium on Conservation of Ecosystem (The 13th SEASTAR2000 Workshop) 2: 39-45.

Wang M, Walker W, Shao K, Chou L. 2003. Feeding Habits of the Pantropical Spotted Dolphin, Stenella attenuata, off the Eastern Coast of Taiwan. Zoological Studies 42(2): 368-378.

Ward R, Zemlak T, Innes B, Last P, Hebert P. 2005. DNA Barcoding of Australia's fish species. Philosophical Transactions of the Royal Society of London. Series B, Biological Sciences 360(1462): 1847-1857.

Zhang JB, Hanner R. 2011. DNA Barcoding is a useful tool for the identification of marine fishes from Japan. Biochemical Systematics and Ecology 39(2011): 31-42. 